Journal of English Language Teaching and Applied Linguistics

ISSN: 2707-756X

DOI: $10.32996 /$ jeltal

Journal Homepage: www.al-kindipublisher.com/index.php/jeltal

\title{
The Integration of ICTs in EFL Teaching in Ecuadorian High Schools: One Country, Two Realities
}

\author{
Jorge Checa Medina 8 (i) \\ Department of Continuing Education, Universidad Técnica de Machala \\ $\triangle$ Corresponding Author: Jorge Checa Medina, E-mail: jcheca@utmachala.edu.ec
}

\begin{tabular}{|c|c|}
\hline ARTICLE INFORMATION & \multirow{2}{*}{$\begin{array}{l}\text { ABSTRACT } \\
\text { This research study starts from the premise that the integration of Information and }\end{array}$} \\
\hline Received: June 09, 2021 & \\
\hline Accepted: July 15, 2021 & Communications Technologies (ICTs) in education is the key to the ultimate \\
\hline Volume: 3 & improvement of EFL teaching. Therefore, the purpose of this study is to determine \\
\hline Issue: 8 & whether the complete integration of ICTs in EFL education in Ecuadorian high schools \\
\hline DOI: $10.32996 /$ jeltal.2021.3.8.1 & $\begin{array}{l}\text { can materialize or not by examining the diverse realities and perceptions of English } \\
\text { teachers and students from public and private high schools. Using the quantitative }\end{array}$ \\
\hline KEYWORDS & methodology, this study analyzed the data obtained by administering surveys \\
\hline & regarding the use of ICTs to 24 English teachers whose ages ranged between 26 to 50 \\
\hline \multirow[t]{8}{*}{$\begin{array}{l}\mathrm{EFL} \text {, ICTs, integration, perceptions, } \\
\text { realities }\end{array}$} & $\begin{array}{l}\text { years old and had teaching experiences that went from } 2 \text { to } 25 \text { years along with } 2520 \\
\text { students whose ages ranged between } 11 \text { to } 17 \text { years old, equally spread among six }\end{array}$ \\
\hline & public and six private Ecuadorian high schools in three different cities: Quito, \\
\hline & $\begin{array}{l}\text { Guayaquil, and Machala. The findings show that private high schools are better } \\
\text { equipped technologically speaking with full access to ICTs, their staff is mostly ready }\end{array}$ \\
\hline & to work with them and their student population has also complete access to ICTs at \\
\hline & $\begin{array}{l}\text { home, at school, and show a positive attitude towards such integration, whereas public } \\
\text { high schools are poorly equipped regarding technology, their teaching staff is under- }\end{array}$ \\
\hline & qualified to work with said technologies in the class and their student population has \\
\hline & $\begin{array}{l}\text { little or no access to them at home, which makes them have a negative attitude towards } \\
\text { such a process. This leads to the conclusion that the successful integration of ICTs in }\end{array}$ \\
\hline & $\begin{array}{l}\text { EFL teaching is only feasible in private Ecuadorian high schools due to their } \\
\text { advantageous position when compared to their public peers. }\end{array}$ \\
\hline
\end{tabular}

\section{Introduction}

This paper focuses on the assertion that Information and Communications Technologies (ICTs) are of paramount importance to break barriers and support education (Inyang, 2017). In the same line of thought, we have Mena et al. (2019) who claim that ICTs are crucial for spreading education worldwide since they are incredibly useful in the adaptation and application of new teaching styles, not to mention the fact that the integration of ICTs in English as a Foreign Language (EFL) teaching has plenty of positive aspects, such as high levels of motivation in students or professional growth and improvement of teaching skills in educators (Drigas \& Charami, 2014).

Within this context of integrating ICTs in EFL education, Sahlin et al. (2017) defined the use of technologies in education as an interesting and impactful process, which can be regarded as a new subfield in education due to its technological nature and its power to spread knowledge where it was not possible before. Following the same reasoning, Wiseman et al. (2018) state that globalization has erased all barriers of teaching and learning English and replaced them with a new scene where it is easier than ever because of all the technological innovations that keep emerging and enable people to learn in better and faster ways. Likewise, Pourhosein (2017) emphasizes that English teaching has dramatically changed, thanks to the integration of technologies in education, which, in turn, have made students' learning more significant and relevant since such ICTs can stimulate our senses and improve all language skills in ways that would not have been possible in traditional classrooms.

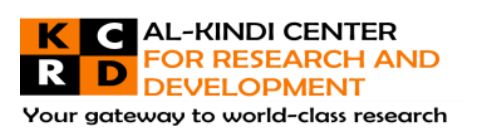

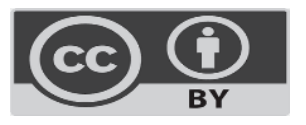

Published by Al-Kindi Center for Research and Development, United Kingdom. Copyright (c) the author(s). This open access article is distributed under a Creative Commons Attribution (CC-BY) 4.0 license 
Additionally, it is worth mentioning that little research has been done on the integration of ICTs in EFL teaching in Ecuadorian high schools. Therefore, the importance of this study lies in filling the existing gap in research due to the scarcity of studies that focus on such topic, which is crucial to examine and analyze to gather more solid information that could lead to the improvement and possible revamping of EFL teaching in Ecuador.

Consequently, the purpose of this study is to determine whether the complete integration of ICTs in EFL education in Ecuadorian high schools can materialize or not by examining the diverse realities and perceptions of English teachers and students from public and private high schools.

\section{Literature Review}

This section presents all the key aspects related to the integration of ICTs in EFL teaching, such as its importance, advantages, disadvantages, methodologies, and the personal and professional perceptions of teachers and students, respectively. It also provides information gathered from previous studies on the use of ICTs in EFL education in Ecuador to have a better perspective of the scope of this work.

\subsection{ICTs in EFL teaching}

Benmarrakchi et al., (2017) argue that the implementation of ICTs in EFL education has changed the way English can be learned remarkably because of its power to break barriers and integrate all the aspects of language education thanks to the different didactic technologies that keep emerging. Papadima-Sophocleous et al. (2014) state that the use of ICTs in EFL teaching is causing a revolution in language education because of the great benefits that arise from said insertion, such as the improvement and even creation of new teaching methodologies, such as blended learning, which is defined by Hockly (2018) as the combination of traditional teaching strategies with the support of online and offline technological resources, such as computers, smart devices or Internet-based software, which enhances the productivity of the EFL class, especially because all these ICTs are very friendly-user and facilitate self-study (Sabri et al., 2020).

Additionally, López (2017) affirms that all the new available technologies we have in education are a great tool for teachers to improve and somehow upgrade their teaching methodologies and be able to keep constantly motivating their students. Jaya Kannan and Pilar Munday, (2018) support this idea by stating that EFL teaching with ICTs helps educators by making all teaching processes, such as planning or finding resources easier and more efficient, which consequently results in students who feel more comfortable and confident of keeping learning. This idea is supported by Huang \& Hong (2016) in their study in which they found that students improved their English understanding and production quite remarkably after their teachers applied the flipped classroom methodology in a short time. All in all, the motivation factor here is crucial given the diversity of resources available that engage students in ways that were not possible before (Azmi, 2017), especially thanks to the flexibility ICTs provide to teachers (Farr \& Murray, 2016), not to mention the positive washback factor, which refers to the idea that good teaching practices encourage students to do better in their tests by practicing and doing their best constantly (Elshawa, 2016).

However, it is also important to analyze any possible disadvantages of implementing ICTs in EFL education. Kara and Cagiltay (2017) warn that the whole teaching and learning process gets seriously compromised when teachers are not well-trained to use ICTs in their teaching processes, which is defined by Xu \& Chen (2016) as technology illiteracy that ends up affecting their teaching efficacy. De Paepe et al. (2018) adds that students are also affected by this problem, especially those that come from low-income groups who, given their living conditions, are highly unlikely to have access to ICTs (Greenhow et al., 2009). This is also supported by Kishore et al. (2019), who acknowledge that the learning gap caused by the impossibility to access such technologies prevent millions of students worldwide from studying anything in both developed and developing countries, which is known as the digital divide and has become an imminent menace to the spread of education (Erdiaw-kwas \& Alam, 2016)

Furthermore, Pérez and Malagón, (2017) argue that integrating ICTs is a highly time-consuming task to perform since they have to find, design, and/or adapt teaching material on several different learning management systems platforms, apps, and other software, which turns to be even more demanding than planning for a traditional class. The same author also mentions that the implementation of all these technologies is expensive to implement and maintain, which puts even more pressure on the teachers, which is why Wang (2017) states that the use of ICTs should be forced on neither students nor teachers.

\section{Methodologies}

Levy (1997) defined the study and use of computers in language teaching as Computer-Assisted Language Learning (CALL), which includes all ICTs. Warschauer and Healey (1998) identified several benefits of using ICTs, such as the possibility to provide instant student feedback, individualization of tasks, project-based activities, or the fun factor that all in all keeps students motivated and enables teachers to polish real-life communication skills thanks to the great variety of resources available. Egbert (2018) clarifies that CALL is not a methodology per se but a collection of physical and digital tools that can be used in language teaching processes, which is also supported by Tafazoli and Golshan, (2014) who defined CALL as a crucial supplementary tool for the English teaching 
and learning process, but also warned that all technological resources must be carefully integrated keeping in mind socio-cultural and infrastructural factors.

Garret (2009) defines CALL as an evolving trend that has combined technology, theory, and pedagogy in an indivisible way. From that perspective, Gruba et al. (2016) argue that the flipped classroom and blended learning approaches are the best options to teach a language.

\subsection{The Flipped Classroom}

The flipped classroom methodology is defined by Rotellar and Cain (2016) as a learner-centered approach without the presence of lectures of any kind that allows students to be exposed to any content in advance to encourage them to learn by creating a connection between the school environment and the rest of the world. In order to do this, computer and internet-based tools are required, such as learning management systems (LMS) or digital classroom management tools to present the students with the content to be learned, which will happen from the convenience of their homes. The final stage will take place in their classrooms where students will put in practice, with the help and guidance of their teachers, what they previously learned by carrying out several activities, such as quizzes, problem-solving situations, or role-plays, among many other options. Chilingaryan and Zvereva (2017) define this methodology as integrated education that marks the beginning of a new era in education that allows students and teachers to be more in contact thanks to the use of ICTs, which have a positive and reassuring effect on language learning.

Moreover, King et al. (2017) define the flipped classroom methodology as a pedagogical process that, given its learner-centered focus, has become largely popular, especially among millennials who are used to the immediacy of the digital era (Cooper et al., 2017). The main and most positive aspect of this methodology is that it promotes scaffolding by encouraging students to build their knowledge based on what they already know to keep expanding it (Riddell et al., 2017), which is supported by Chen Hsieh et al (2017) who identified conclusive evidence in their study on the use of the flipped classroom in the EFL classroom that students who learn with this approach learn faster, can use different language structures in a better way than their counterparts who do not learn with this methodology and keep high and constant levels of motivation to keep learning.

\subsection{Blended Learning}

Nevertheless, unlike the flipped classroom methodology, which relies on a second stage that takes place on-site, the blended learning approach relies on all sorts of online resources, thus reducing the amount of on-site learning to none (Stein et al., 2020). The same authors define blended learning as a mixture of online experiences aimed at making the teaching and learning process a more flexible and pleasant experience by turning every activity into a highly interactive situation, which engages all participants in a way that is not possible in traditional classrooms, especially in language learning environments where students can achieve better academic results that are easily measurable and verifiable. It is also worth noting that Stein et al. also add that even though the implementation of blended learning may be a little difficult to implement and maintain at first, it helps decrease all costs in the long run by eliminating all the on-site requirements of a traditional school.

Also, it is important to analyze that blended learning has made the concept of flexibility in education a reality more than ever before by encouraging constant social interaction among all participants, which promotes an effective learning environment (Boelens et al., 2017). Another benefit of this approach is that it enhances the student's learning potential by providing them with a wide array of options to learn, such as learning apps or gamification websites that motivate them in unprecedented ways (Cheung et al., 2018). Arkhipova et al. (2018) reinforce this idea by stating that language students of all ages are both neurobiologically and psychologically motivated to keep learning with this approach independently of their age, which means that the use of ICTs in language education is no longer an option but an obligation.

\subsection{Teachers' characteristics and perceptions}

Using ICTs in the EFL classroom is a challenge in itself and therefore, they need to be resilient so that they can handle the extra workload that implementing different technologies in the class may bring (Aldama \& Pozo, 2016). That extra workload is a real threat that may cause teachers to suffer from neuroticism, which means that they are likely to suffer from anxiety, frustration, or even depression, triggered by a new teaching style, especially when they're not used to it, especially at older ages (Laabidi \& Laabidi, 2016). Nikolopoulou and Gialamas (2015) add that teachers also need to be highly perceptive not only to deal with their teaching situations but also with the realities of their students, especially in those environments where the use of ICTs is not a common reality.

Additionally, Göncz (2017) points that teachers implementing ICTs in the EFL classroom must possess a great level of vocation because carrying out such a process is highly challenging because they have to focus not only on helping their students develop language skills but also on improving their technical skills and be able to lead their students in such process. This is why teachers must be dynamic individuals with great problem-solving skills to cope with all these new tasks and skills to be learned and mastered so that they can overcome any problems that may arise (Barnes \& Kennewell, 2017). Bai et al. (2016) also mention that when ICTs 
are to be used in the EFL class, teachers must be coherent when choosing them, especially in terms of the student's socioeconomic status because they may never have been exposed to such tools or teaching approaches before. In that case, McKnight, et al. (2016) advise teachers to be resourceful and creative in the use of ICTs in a way that is easy and approachable to all students.

Moreover. Player-Koro (2012) highly advises teachers implementing ICTs in the EFL class to be accessible to all students so that they can feel safe and understood within this new teaching and learning environment. Mathipa \& Mukhari (2014) add to this idea by stating that teachers must also be able to provide emotional support whenever it is needed, especially in those long-distance learning environments.

In terms of teachers' needs, Salem \& Mohammadzadeh (2018) mention that teachers implementing ICTs in the EFL class (or about to) report the need for constant professional development given the very own dynamic nature of such technologies that can be used in their teaching processes and also claim that they cannot succeed in this endeavor without the help and support from their school administrators and education policy-makers at government level, which is supported by Galanouli et al. (2004) who argue that if teachers are not properly trained in the use of ICTs in the EFL class with effective and meaningful training, they are bound to fail just like and no education system should ever let their teachers alone in such a big enterprise. This is the main reason why English teachers are reluctant to finally implement ICTs in their classes, and in most cases, they will not do so unless they are forced to do so (Sari et al., 2017).

Additionally, Prasad et al. (2015) mention that English teachers are also reluctant to use ICTs in their classes because of limited or no technical support from their schools, lack of access to technologies, and network connection difficulties, especially in developing countries that have a $44 \%$ average access to the Internet and other technologies, with some countries not even reaching the $20 \%$ average threshold (Pew Research Center, 2015) and Khan et al. (2019) warn that unless that gap in technology is closed, education that relies on ICTs will never be a reality because of the obvious limitations.

Students' characteristics and perceptions

Prensky (2001) defined today's students as digital natives, people who have fundamentally changed in comparison to their previous generation because they have been exposed from a very early age to different technologies in the shape of computers, videogames, or cell phones among an almost endless variety of technological advances that have helped them to effortlessly understand and interiorize the language of such technologies. This explains why Izadpanah (2016) found that students learning EFL with ICTs show a positive attitude towards the use of different technologies in the classroom and are willing and eager to keep working in such a manner.

Additionally, Gong et al. (2019) found that students feel that the use of ICTs in the classroom help them improve their English skills in a way that is connected to real-life situations, which gives them a sense of practical purpose and self-reflection, but they are also worried that their teachers may not be entirely prepared to work with technologies more extensively and systematically, which happens because students are used to traditional teaching styles and perceive their teachers as some sort of knowledge vessels who are reluctant to innovate and change (Taylor \& Packham, 2016)

Nevertheless, Zainuddin and Attaran (2016) found that despite the positive attitude shown by most students towards the use ICTs in their classes, they are also worried that they may not be able to have access to all the required technologies such as computers or smart devices and Internet connectivity due to their different economic backgrounds, which will prevent them from keeping studying, especially in those classes where teachers decide to teach almost exclusively with ICTs or in distance-learning education systems.

\subsection{Previous studies on the use of ICTs in EFL education in Ecuador}

Toledo and Campuzano (2017) wrote a literature review on the potential role of technology in English education in Ecuador and concluded that technologies, despite their usefulness, are not being properly implemented in Ecuadorian EFL classrooms due to economic factors and the lack of a solid pedagogical model to follow. It is worth mentioning that this review was done by comparing how developed countries use technology in their education systems in a rather general way against what happens in Ecuador in terms of EFL teaching.

Moreover, Solano et al. (2017) carried out a study that focused on exploring the use of technology in EFL teaching in Southern Ecuadorian schools by applying quantitative and qualitative methodologies through the application of surveys and interviews with a population of 150 students and 15 teachers over six months and found that technologies are not being properly used either because of the lack of access to ICTs or because of teachers who are not well-trained and show reluctance to implement them in their pedagogical processes, without even considering that students claim to feels more motivated to learn English with them. 
Besides, Acosta \& Cajas (2018) carried out a study on the teaching resources used in EFL classes in both public and private Ecuadorian universities and applied surveys on 65 teachers to figure out what type of resources and how often they used them in class and concluded that ICTs were rarely used in their classes in favor of printed material of all sources, especially printed textbooks because of their ease of use when compared to the planning of a class that relies more on ICTs.

\section{Methodology}

This section presents information on where the research process to collect data for this project took place, the people involved in it, along the methodology and research procedures that were put into practice.

As shown in the previous section, there is no specific research that focuses exclusively on the integration of ICTs in the EFL class in Ecuadorian high schools, not to mention the fact that we are living in an unprecedented situation that is forcing us to take a teaching and learning paradigm shift. Therefore, it is vital to proceed with this study to answer the following research question:

Are English teachers and students from public and private Ecuadorian high schools ready to fully integrate ICTs in their teaching and learning processes?

\subsection{Setting and participants}

The process to gather the required data took place in three different cities in Ecuador: Quito, Guayaquil, and Machala across two public and two private high schools in each city, respectively, with a total of 12 participant institutions from January 20 to January 24, 2021. Two English teachers per school, with a total of 24 participant educators whose ages ranged from 26 to 50 years old and teaching experiences that went from 2 to 25 years, were surveyed regarding their perception of the use of ICTs in the EFL class and on what ICTs they use. The criteria to choose the participant public and private schools is their student-teacher ratio, which, on average is 36:1, their curriculum, which includes English as a compulsory subject, and years of service to the community, which on average is 50 years. The teachers were asked to participate as volunteers via email and once they accepted to do so, they proceeded as instructed with their students to collect all the data.

Table 1 : Participant English teachers

\begin{tabular}{|c|c|c|c|c|c|}
\hline $\mathrm{N}^{\circ}$ & Gender & Age & Nationality & Type of high school & $\begin{array}{l}\text { Teaching experience in } \\
\text { years }\end{array}$ \\
\hline 1 & Male & 41 & Ecuadorian & Public & 15 \\
\hline 2 & Male & 34 & Ecuadorian & Public & 7 \\
\hline 3 & Male & 38 & Ecuadorian & Public & 13 \\
\hline 5 & Male & 41 & Ecuadorian & Public & 19 \\
\hline 6 & Male & 50 & Ecuadorian & Public & 24 \\
\hline 7 & Female & 45 & Ecuadorian & Public & 20 \\
\hline 10 & Female & 35 & Ecuadorian & Public & 8 \\
\hline 11 & Female & 30 & Ecuadorian & Public & 6 \\
\hline 12 & Female & 39 & Ecuadorian & Public & 14 \\
\hline 13 & Male & 28 & Ecuadorian & Private & 4 \\
\hline 14 & Male & 33 & Ecuadorian & Private & 7 \\
\hline 15 & Male & 35 & Ecuadorian & Private & 9 \\
\hline 16 & Male & 26 & Ecuadorian & Private & 2 \\
\hline
\end{tabular}




\begin{tabular}{llllll}
\hline 19 & Female & 27 & Ecuadorian & Private & 3 \\
\hline 20 & Female & 36 & Ecuadorian & Private & 10 \\
\hline 21 & Female & 34 & Ecuadorian & Private & 8 \\
\hline 22 & Female & 33 & Ecuadorian & Private & 25 \\
\hline 23 & Female & 47 & Ecuadorian & Private & 16 \\
\hline 24 & Female & 43 & Ecuadorian & & Private \\
\hline
\end{tabular}

Additionally, considering that each teacher in Ecuador has, on average, four classes with 36 students in each classroom (INEVAL, 2018), every participant teacher was asked to apply a survey to their students on their perception of the use of ICTs in their English classes. Each teacher had to survey 105 students to be able to collect reliable responses with a confidence level of $95 \%$ and a $5 \%$ margin of error, giving a total of 2520 participant students, whose ages ranged from 11 to 17 . The students were surveyed from January 27 to January 31, 2020.

Table 2 : Participant students from public high schools

\begin{tabular}{llll}
\hline Gender & Age range & Students & $\%$ \\
\hline Male & $11-12$ & 201 & 15.95 \\
\hline Female & $11-12$ & 172 & 13.65 \\
\hline Male & $13-14$ & 257 & 20.40 \\
\hline Female & $13-14$ & 210 & 16.67 \\
\hline Male & $15-17$ & 229 & 18.17 \\
\hline Female & $15-17$ & 191 & 15.16 \\
\hline & TOTAL & 1260 & 100 \\
\hline
\end{tabular}

Table 3 : Participant students from private high schools

\begin{tabular}{llll}
\hline Gender & Age range & Students & $\%$ \\
\hline Male & $11-12$ & 187 & 14.84 \\
\hline Female & $11-12$ & 206 & 16.35 \\
\hline Male & $13-14$ & 237 & 18.81 \\
\hline Female & $13-14$ & 199 & 15.79 \\
\hline Male & $15-17$ & 263 & 20.87 \\
\hline Female & $15-17$ & 168 & 13.33 \\
\hline & TOTAL & 1260 & 100
\end{tabular}

\subsection{Procedure}

Firestone (1987) argues that the quantitative methodology is the most suitable approach to analyze a phenomenon where there are multiple social realities. Therefore, that was the method of choice for this research project. The participant teachers were administered an eight-question survey regarding their perceptions of the use of ICTs in the EFL class and the participant students were administered a five-question survey regarding their perception of learning with ICTs. The objective of the surveys administered to both the students and teachers was to determine how ready they may be to start using ICTs in their EFL classes in a more comprehensive fashion. All surveys used a five-point scale and were administered over a period of ten days. In that regard, the participant schools agreed to contribute to this project after having formally asked the Principals of every participant school via formal requests explaining the goal and scope of this research project, which were sent and approved between January 6 to January 15,2021 . Once approved, all the participant teachers were provided with a link to respond to their survey via Google forms 
and were also provided with the survey to be administered to their students. Once all the required information was gathered, it was finally sent back to the researcher to be processed and analyzed.

\section{Results}

In this section, a description of the data collected through the surveys, which were processed in Microsoft Excel and JASP, will be presented in detail to try to elicit key points to answer the research question that drives this project. The participant teachers from both public and private schools were administered an eight-question survey and the participant students from the same schools were administered a five-question survey. The results are shown in the tables below:

Table 4 : Teachers' realities and perceptions on the use of ICTs in public high schools

\begin{tabular}{|c|c|c|c|c|c|}
\hline \multirow[t]{3}{*}{ Statement } & STRONGLY & AGREE & NO & DISAGREE & \multirow{3}{*}{$\begin{array}{l}\text { STRONGLY } \\
\text { DISAGREE } \\
\%\end{array}$} \\
\hline & \multicolumn{2}{|l|}{ AGREE } & \multicolumn{2}{|l|}{ ANSWER } & \\
\hline & $\%$ & $\%$ & $\%$ & $\%$ & \\
\hline $\begin{array}{l}\text { I can overcome any technical } \\
\text { problems that may emerge when } \\
\text { using ICTs in my classes. }\end{array}$ & 0.00 & 0.00 & 0.00 & 0.00 & 100.00 \\
\hline I have full access to ICTs at school & 0.00 & 0.00 & 0.00 & 0.00 & 100.00 \\
\hline I have full access to ICTs at home. & 83.33 & 16.67 & 0.00 & 0.00 & 0.00 \\
\hline $\begin{array}{l}\text { Integrating ICTs in education is a } \\
\text { necessary step to improve language } \\
\text { learning. }\end{array}$ & 25.00 & 41.67 & 0.00 & 33.33 & 0.00 \\
\hline $\begin{array}{l}\text { My students are highly motivated to } \\
\text { use ICTs in our classes. }\end{array}$ & 0.00 & 33.33 & 0.00 & 66.67 & 0.00 \\
\hline $\begin{array}{l}\text { Age is an obstacle for a teacher to } \\
\text { integrate ICTs in an English class. }\end{array}$ & 75.00 & 25.00 & 0.00 & 0.00 & 0.00 \\
\hline $\begin{array}{l}\text { My school gives me plenty of } \\
\text { opportunities to learn about ICTs to } \\
\text { improve my classes. }\end{array}$ & 0.00 & 0.00 & 0.00 & 33.33 & 66.67 \\
\hline $\begin{array}{l}\text { I know how to apply different } \\
\text { methodologies and strategies to fully } \\
\text { integrate ICTs in my classes. }\end{array}$ & 0.00 & 16.67 & 0.00 & 33.33 & 50.00 \\
\hline
\end{tabular}

$$
\mathrm{N}=12
$$

Table 5:Teachers' realities and perceptions on the use of ICTs in private high schools

\begin{tabular}{|c|c|c|c|c|c|}
\hline \multirow[t]{3}{*}{ Statement } & STRONGLY & AGREE & NO & DISAGREE & \multirow{2}{*}{$\begin{array}{l}\text { STRONGLY } \\
\text { DISAGREE }\end{array}$} \\
\hline & \multicolumn{2}{|l|}{ AGREE } & \multicolumn{2}{|c|}{ ANSWER } & \\
\hline & $\%$ & $\%$ & $\%$ & $\%$ & $\%$ \\
\hline $\begin{array}{l}\text { I can overcome any technical } \\
\text { problems that may emerge } \\
\text { when using ICTs in my classes. }\end{array}$ & 0.00 & 0.00 & 0.00 & 16.67 & 83.33 \\
\hline
\end{tabular}




\begin{tabular}{|c|c|c|c|c|c|}
\hline $\begin{array}{l}\text { I have full access to ICTs at } \\
\text { school }\end{array}$ & 100.00 & 0.00 & 0.00 & 0.00 & 0.00 \\
\hline $\begin{array}{l}\text { I have full access to ICTs at } \\
\text { home. }\end{array}$ & 100.00 & 0.00 & 0.00 & 0.00 & 0.00 \\
\hline $\begin{array}{l}\text { Integrating ICTs in education } \\
\text { is a necessary step to improve } \\
\text { language learning. }\end{array}$ & 66.67 & 33.33 & 0.00 & 0.00 & 0.00 \\
\hline $\begin{array}{l}\text { My students are highly } \\
\text { motivated to use ICTs in our } \\
\text { classes. }\end{array}$ & 83.33 & 16.67 & 0.00 & 0.00 & 0.00 \\
\hline $\begin{array}{l}\text { Age is an obstacle for a } \\
\text { teacher to integrate ICTs in an } \\
\text { English class. }\end{array}$ & 58.33 & 41.67 & 0.00 & 0.00 & 0.00 \\
\hline $\begin{array}{l}\text { My school gives me plenty of } \\
\text { opportunities to learn about } \\
\text { ICTs to improve my classes. }\end{array}$ & 66.67 & 33.33 & 0.00 & 0.00 & 0.00 \\
\hline $\begin{array}{l}\text { I know how to apply different } \\
\text { methodologies and strategies } \\
\text { to fully integrate ICTs in my } \\
\text { classes. }\end{array}$ & 25.00 & 33.33 & 0.00 & 41.67 & 0.00 \\
\hline
\end{tabular}

$\mathrm{N}=12$

The comparison of data presented in tables 4 and 5 shows that the vast majority of English teachers from both public and private high schools were not ready to overcome any technical problems related to the use of ICTs in the EFL class.

The number of teachers who had access to ICTs at school was dramatically larger than their public high school peers who did not have any access to them. Additionally, all teachers reported having access to ICTs at home and almost all participant teachers agreed with the idea that ICTs are a necessary step to improve EFL education with an almost complete combined level of agreement. There is a significant difference in terms of what teachers think about the attitude shown by their students towards the use of ICTs in class; more than half of the public school teachers acknowledged their students are not motivated to use technologies in the class compared to the almost complete majority of private school teachers who reckoned their students are motivated to use them. Moreover, there is a dramatic level of agreement concerning age when using ICTs between public and private teachers because all of them consented to a higher or lower degree that age can be an impediment to use ICTs properly in the EFL class.

Furthermore, there is a significant level of disagreement between the opportunities public and private high schools provided to teachers. All the public school teachers disagreed with the idea that their schools provide them with opportunities to learn to use ICTs, whereas the entirety of their private school peers agreed with that statement. Finally, most of the public school teachers reported ignoring how to fully integrate ICTs in their pedagogical processes, and almost half of the private school teachers also reported the same. 
Table 6 : Students' realities and perceptions on the use of ICTs in public high schools

\begin{tabular}{|c|c|c|c|c|c|}
\hline \multirow[t]{3}{*}{ Statement } & STRONGLY & AGREE & NO & DISAGREE & \multirow{2}{*}{$\begin{array}{l}\text { STRONGLY } \\
\text { DISAGREE }\end{array}$} \\
\hline & \multicolumn{2}{|l|}{ AGREE } & \multicolumn{2}{|l|}{ ANSWER } & \\
\hline & $\%$ & $\%$ & $\%$ & $\%$ & $\%$ \\
\hline $\begin{array}{l}\text { I feel more motivated and } \\
\text { engaged when I use ICTs in my }\end{array}$ & 7.78 & 5.95 & 0.00 & 65.32 & 20.95 \\
\hline English class. & & & & & \\
\hline $\begin{array}{l}\text { Learning through ICTs makes } \\
\text { learning English easier. }\end{array}$ & 7.06 & 8.02 & 0.00 & 52.06 & 32.86 \\
\hline $\begin{array}{l}\text { I have full access to ICTs at } \\
\text { school }\end{array}$ & 0.00 & 0.00 & 0.00 & 62.62 & 37.38 \\
\hline $\begin{array}{l}\text { I have full access to ICTs at } \\
\text { home. }\end{array}$ & 7.90 & 6.25 & 0.00 & 21.83 & 64.02 \\
\hline $\begin{array}{l}\text { I would recommend English } \\
\text { teachers to use ICTs in all their } \\
\text { classes. }\end{array}$ & 4.37 & 6.43 & 0.00 & 18.80 & 70.40 \\
\hline
\end{tabular}

$N=1260$

Table 7: Students' realities and perceptions on the use of ICTs in private high schools

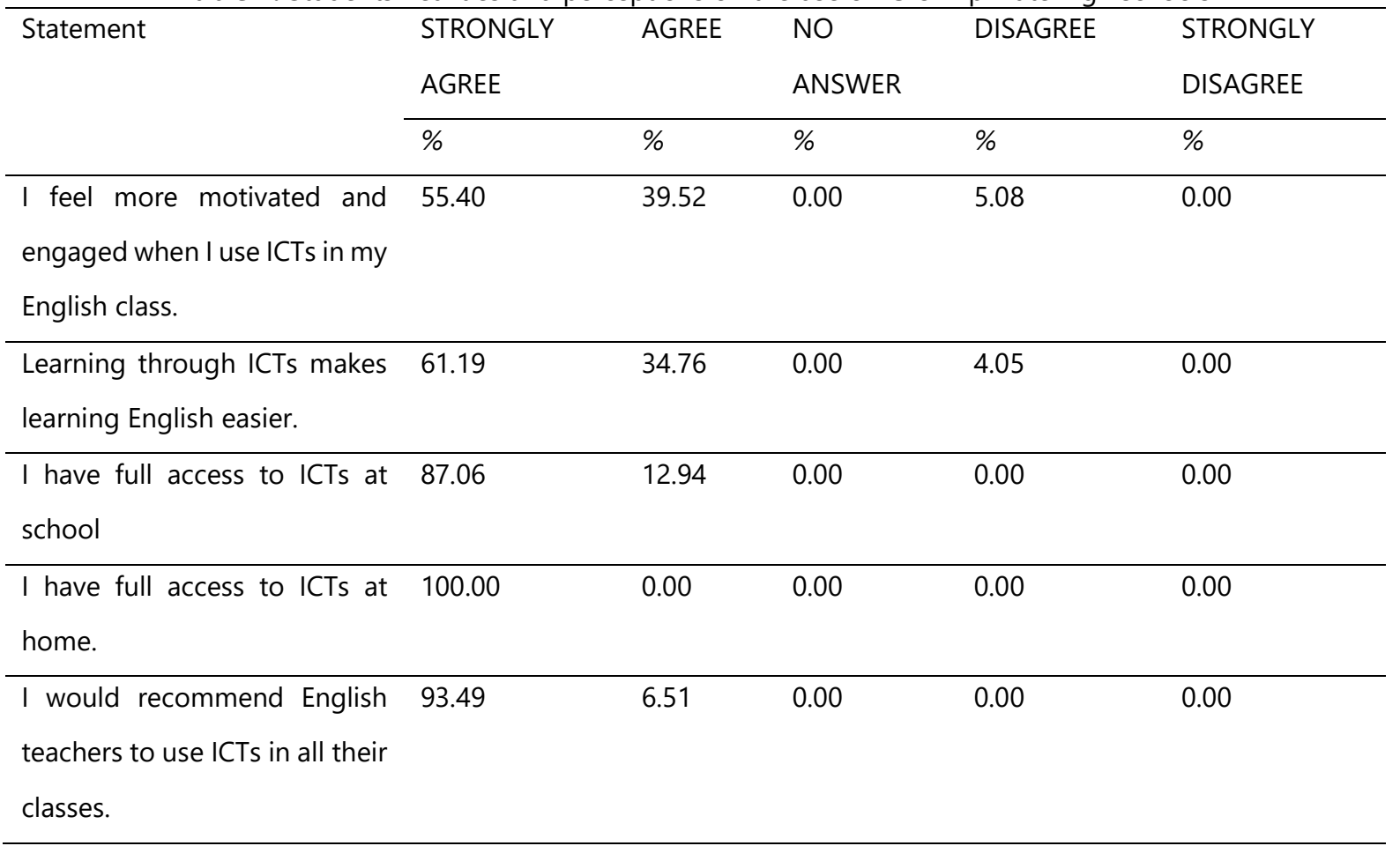

$N=1260$

The comparison of data presented in tables 6 and 7 shows that there is a significant difference between what the students of public and private high schools think in terms of motivation towards the use of ICTs in the EFL class. The students from public high schools feel completely unmotivated to use ICTs in the EFL class, whereas their counterparts feel the opposite, which is also reflected with the same levels of agreement and disagreement on the idea that learning through ICTs makes learning English easier. 
Additionally, the difference in access to ICTs at school is dramatic between both groups. Most students from public high schools have a complete lack of access to ICTs there, whereas their counterparts have complete access to them at their schools. Furthermore, ICT access at home is similar in terms of percentages since only an alarming minority of the participant students from public high schools have access to ICTs at home while all the students from private high schools have complete access to them. Finally, the vast majority of the participant students from public institutions would not recommend the use of ICTs in their EFL classes, whereas their counterparts are in favor of such recommendations.

\section{Discussion}

In this section, a comprehensive analysis of the results will be performed to understand all the sides and aspects that were part of this study, whose findings seem to prove the successful integration of ICTs in EFL education in Ecuadorian high schools can only become half a reality.

Regarding the research question, it is interesting to observe that most teachers from both types of schools were not ready to deal with any technical problems they may experience while teaching with ICTs. Barnes and Kennewell (2017) refer to this as an obstacle that will prevent them from teaching with ease in an ICT-based environment. This is rather surprising considering that, even though public high school teachers do not have access to ICTs at school, all the participant teachers declared to have complete access to them at home. This could be a sign that they are not trying to innovate their pedagogical processes, which is an idea supported by McKnight, et al. (2016). This is an unexpectedly contradictory fact when compared to their complete agreement with the idea that ICTs are essential in EFL education, which could be interpreted as a simplistic way to accept their usefulness in education, but at the same time do not take the necessary steps to be ready to use them. Xu and Chen (2016) refer to this as technology illiteracy, which is a potential threat to all pedagogical processes that involve the use of many technologies that can be even worsened when school administrators do not provide their teachers with the necessary help and support to bridge that gap in technological knowledge by not giving them enough options to learn the use of ICTs, albeit they may as well learn to master those technologies on their own.

Unsurprisingly, the difference observed by the teachers in their students in terms of a positive attitude towards ICTs is radically different because private high schools are fully equipped with ICTs, so their students are highly motivated to use them while public high schools are under-equipped and their students feel quite the opposite. This idea is supported by De Paepe et al. (2018) who argue that teachers typically see such low levels of motivation in students at public schools due to the lack of access to ICTs, especially in developing countries.

Interestingly enough, all teachers agreed with the idea that age can be a problem in terms of successfully working with ICTs; yet this turns much more noteworthy when checking their average age, which is 36. Laabidi and Laabidi (2016) refer to the age in education that involves ICTs as a rather psychological factor related to an overload of emotions and frustration that make them feel they are not ready to work with such technologies due to their age. However, they may also be suffering the same effects because they are considered, according to Prensky (2001), as digital immigrants who naturally struggle with the use of ICTs at higher or lower degrees.

Additionally, it is rather shocking that teachers do not know how to apply the necessary methodologies and strategies to integrate ICTs in their pedagogical processes regardless of the type of school where they teach. This idea is supported by Göncz's (2017) findings that indicate that teachers must always have a great and constant sense of vocation that drives them to keep improving their teaching skills and knowledge.

Moreover, considering the level of ICT equipment both types of schools possess, which is diametrically different, public high school students are neither motivated to use ICTs in the EFL class nor ready to do so, whereas their counterparts are exactly the opposite, which is supported by Izadpanah (2016) who argues that those students who are surrounded by a technology-based learning environment tend to naturally feel more motivated and consequently, learn more easily.

Finally, there is a huge difference in terms of access to ICTs at home. The vast majority of public high school students do not have access to them whereas their counterpart peers have complete access to them. According to a report issued by INEC (2018), only $24.25 \%$ of the Ecuadorian population have access to a computer at home and $16.1 \%$ have access to the Internet. This means that those students without access to said technologies will not be able to learn EFL properly in an ICT-based environment, which is supported by Zainuddin and Attaran (2016) who argue that this situation is especially repeated in public schools from developing countries. Therefore, those students who come from public high schools advise against the use of ICTs in the EFL class while those from private schools are in total favor of that idea. 


\section{Conclusion}

It is crucial to understand that this study aimed to fill the gap in the existing literature that either focused on the use of ICTs in primary schools or universities in Ecuador but ignores the state of ICT integration in high schools. Consequently, the objective of this study was to determine whether the amalgamation of ICTs and EFL education in Ecuadorian high schools can truly happen or not. Overall, the findings show that such integration is only feasible within the private Ecuadorian high schools system because they possess all the necessary technological infrastructure and most of their teaching staff is well-trained to embark on this teaching paradigm, not to mention the fact that their students also have complete access to ICTs at home, which enables them to learn with ease. On the other hand, not only are the Ecuadorian public high schools at an enormous disadvantage technologically speaking, but also in terms of the teaching staff who is not well-prepared to endeavor to fully integrate ICTs in their pedagogical processes. Besides, their student population belongs to the minorities and low-income groups with little or no access to technologies, which results in the impossibility of integrating ICTs in such schools.

The outcome of this study concords with other previous studies conducted on ICT integration in the Ecuadorian EFL classroom, which also concluded that such incorporation was not possible in public schools due to socio-economic factors and the lack of well-trained teachers in the use of ICTs. However, from a broader perspective, the results of this research can easily be transferred to other school subjects and other (if not all) levels of education. Therefore, the pedagogical implications of this study are rather extensive since the whole education system has been forced to take a paradigm shift to exclusively rely on distance learning due to the worldwide reality we are living nowadays and may positively contribute to improving education at all levels by taking in consideration all the aspects exposed throughout this work, especially in terms of finding ways to bridge the gap between private and public education concerning infrastructure, teaching training and socio-economic factors.

All in all, the integration of ICTs in EFL education in Ecuadorian high schools has been proved to be possible only for those with a good socioeconomic status, leaving behind those who belong to the most vulnerable and poorest sectors of the society who struggle to live each day and hardly ever have the luxury of a computer or Internet access. Thus, the main contribution this study intends to achieve is to raise awareness of the fact that education is not and should never be a luxury but an inalienable right, and we, as educators, should fight for that idea to never be surrendered or forgotten so that one day, we can stop talking about Ecuador as a country that has two radically different educational realities in terms of technology integration.

\section{Limitations of the study}

This study was carried in only three of the most important cities of Ecuador. Despite their importance in the country, the findings may not be applicable to the whole country due to the relatively small population considered for this project.

\section{Recommendations for future research}

Considering the limitations of this study, it may be important for future researchers trying to expand on the findings presented in this project to cover smaller cities and even rural areas to have a deeper understanding of how ICTs are being integrated in Ecuadorian education system.

Funding: This research received no external funding.

Acknowledgments: The author would like to thank all the teachers and students who participated in this study.

Conflicts of Interest: The author declares no conflict of interest.

\section{References}

[1] Acosta, H., \& Cajas, D. (2018). Analysis of teaching resources used in EFL classes in selected Ecuadorian universities. International Journal of Applied Linguistics, 8(1), 100-109. https://doi.org/10.17509/ijal.v8i1.11469

[2] Agbo, I. (2015). Factors influencing the use of information and communication technology (ICT) in teaching and learning computer studies in Ohaukwu local government area of Ebonyi state-Nigeria. Journal of Education and Practice, 6(7), 71-86.

[3] Aldama, C., \& Pozo, J. (2016). How are ICT used in the classroom? A study of teachers' beliefs and uses. Electronic Journal of Research in Educational Psychology, 2, 253-286. https://doi.org/10.14204/ejrep.39.15062

[4] Arkhipova, M. V., Belova, E. E., Gavrikova, Y. A., Lyulyaeva, N. A., \& Shapiro, E. D. (2018). Blended Learning in Teaching EFL to Different Age Groups. Advances in Intelligent Systems and Computing, 380-386. https://doi.org/10.1007/978-3-319-75383-6_49

[5] Azmi, N. (2017). The benefits of using ICT in the EFL classroom: From perceived utility to potential challenges. Journal of Educational and Social Research, 7(1), 111-112. https://doi.org/10.5901/jesr.2017.v7n1p111

[6] Bai, Y., Mo, D., Zhang, L., Boswell, M., \& Rozelle, S. (2016). The impact of integrating ICT with teaching: Evidence from a randomized controlled trial in rural schools in China. Computers and Education, 96, 1-14. https://doi.org/10.1016/j.compedu.2016.02.005

[7] Barnes, J., \& Kennewell, S. (2017). Investigating teacher perceptions of teaching ICT in Wales. Education and Information Technologies, 22(5), 2485-2497. https://doi.org/10.1007/s10639-016-9549-y

[8] Benmarrakchi, F., El Kafi, J., Elhore, A., \& Haie, S. (2017). Exploring the use of the ICT in supporting dyslexic students' preferred learning styles: A preliminary evaluation. Education and Information Technologies, 22(6), 2939-2957. https://doi.org/10.1007/s10639-016-9551-4 
[9] Boelens, R., De Wever, B., \& Voet, M. (2017). Four key challenges to the design of blended learning: A systematic literature review. Educational Research Review, 22, 1-18. https://doi.org/10.1016/j.edurev.2017.06.001

[10] Chen Hsieh, J. S., Wu, W.-C. V., \& Marek, M. W. (2017). Using the flipped classroom to enhance EFL learning. Computer Assisted Language Learning, 30(1-2), 1-21. https://doi.org/10.1080/09588221.2015.1111910

[11] Cheung, S. K. S., Wang, F. L., Au, O., \& Xie, Y. (2018). Guest editorial: Innovative Practices of Blended Learning. Open Learning: The Journal of Open, Distance and e-Learning, 33(2), 80-82. https://doi.org/10.1080/02680513.2018.1455579

[12] Chilingaryan, K., \& Zvereva, E. (2017). Methodology of Flipped Classroom as a Learning Technology in Foreign Language Teaching. Education, Health and ICT for a Transcultural World, 237, 1500-1504. https://doi.org/10.1016/j.sbspro.2017.02.236

[13] Cooper, A. Z., Hsieh, G., Kiss, J. E., \& Huang, G. C. (2017). Flipping Out: Does the Flipped Classroom Learning Model Work for GME? Journal of Graduate Medical Education, 9(3), 392-393. PubMed. https://doi.org/10.4300/JGME-D-16-00827.1

[14] De Paepe, L., Zhu, C., \& Depryck, K. (2018). Online Dutch L2 learning in adult education: Educators' and providers' viewpoints on needs, advantages and disadvantages. Open Learning: The Journal of Open, Distance and e-Learning, 33(1), 18-33. https://doi.org/10.1080/02680513.2017.1414586

[15] Drigas, A., \& Charami, F. (2014). ICTs in English Learning and Teaching. International Journal of Recent Contributions from Engineering, Science \& IT (IJES), 2, 4-10. https://doi.org/10.3991/ijes.v2i4.4016

[16] Elshawa, N. (2016). Teachers' assessment literacy and washback effect of assessment. International Journal of Applied Linguistics \& English Literature, 5(4). https://doi.org/10.7575/aiac.ijalel.v.5n.4p.135

[17] Erdiaw-kwas, M., \& Alam, K. (2016). Towards understanding digital divide in rural partnerships and development: A framework and evidence from rural Australia. Journal of Rural Studies, 43, 214-224. https://doi.org/10.1016/j.jrurstud.2015.12.002

[18] Farr, F., \& Murray, L. (2016). The Routledge Handbook of Language Learning and Technology (Routledge Handbooks in Applied Linguistics). Routledge.

[19] Firestone, W. (1987). Meaning in Method: The Rhetoric of Quantitative and Qualitative Research. Educational Researcher, $16(7), 16-21$. https://doi.org/10.3102/0013189X016007016

[20] Galanouli, D., Murphy, C., \& Gardner, J. (2004). Teachers' perceptions of the effectiveness of ICT-competence training. 21st Century Learning: Selected Contributions from the CAL 03 Conference, 43(1), 63-79. https://doi.org/10.1016/j.compedu.2003.12.005

[21] Garret, N. (2009). Computer-Assisted Language Learning Trends and Issues Revisited: Integrating Innovation. The Modern Language Journal, 93(s1), 719-740. https://doi.org/10.1111/j.1540-4781.2009.00969.x

[22] Göncz, L. (2017). Teacher personality: A review of psychological research and guidelines for a more comprehensive theory in educational psychology. Open Review of Educational Research, 4(1), 75-95. https://doi.org/10.1080/23265507.2017.1339572

[23] Gong, Q., Kawasaki, K., Yeung, W. L., Zhang, G., \& Dobinson, T. (2019). Students' Perceptions of the Use of Video Recording in Additional Language Oral Assessments. In T. Dobinson \& K. Dunworth (Eds.), Literacy Unbound: Multiliterate, Multilingual, Multimodal (pp. 133-152). Springer International Publishing. https://doi.org/10.1007/978-3-030-01255-7_8

[24] Greenhow, C., Walker, J. D., \& Kim, S. (2009). Millennial Learners and Net-Savvy Teens? Examining Internet Use among Low-Income Students. Journal of Computing in Teacher Education, 26(2), 63-68. https://doi.org/10.1080/10402454.2009.10784634

[25] Gruba, P., Hinkelman, D., \& Cárdenas-Claros, M. (2016). New technologies, blended learning and the 'flipped classroom' in ELT. In Routledge handbook of English language teaching. Routledge.

[26] Hockly, N. (2018). Blended Learning. ELT Journal, 72(1), 97-101. https://doi.org/10.1093/elt/ccx058

[27] Huang, Y.-N., \& Hong, Z.-R. (2016). The effects of a flipped English classroom intervention on students' information and communication technology and English reading comprehension. Educational Technology Research and Development, 64(2), 175-193. https://doi.org/10.1007/s11423-015-9412-7

[28] INEC. (2018). Tecnologías de la Información y Comunicación [Statistical]. Instituto Nacional de Estadísticas y Censos. https://www.ecuadorencifras.gob.ec/tecnologias-de-la-informacion-y-comunicacion-tic/

[29] INEVAL. (2018). Educación en Ecuador resultados de PISA para el desarrollo (pp. 82-84). Instituto nacional de evaluación educativa. http://www.evaluacion.gob.ec/evaluaciones/pisa-documentacion/

[30] Inyang, J. B. (2017). The use of information and communication technologies (ICTs) in foreign language teaching in Nigeria: Prospects and challenges. International Journal of Arts and Humanities (IJAH), 6(1). http://dx.doi.org/10.4314/ijah.v6i1.11

[31] Izadpanah, S. (2016). The perception of EFL high school students in using of computer technology in the process of learning: Merits and demerits. Advances in Language and Literary Studies, 7(3). https://doi.org/10.7575/aiac.alls.v.7n.3p.146

[32] Jaya Kannan \& Pilar Munday. (2018). New Trends in Second Language Learning and Teaching through the lens of ICT, Networked Learning, and Artificial Intelligence. Círculo de Lingüística Aplicada a La Comunicación, 76(0). https://doi.org/10.5209/CLAC.62495

[33] Kara, N., \& Cagiltay, K. (2017). In-service preschool teachers' thoughts about technology and technology use in early educational settings. Comtemporary Educational Technology, 8(2), 119-141. https://doi.org/10.30935/cedtech/6191

[34] Khan, S., Hwang, G.-J., Azeem Abbas, M., \& Rehman, A. (2019). Mitigating the urban-rural educational gap in developing countries through mobile technology-supported learning. British Journal of Educational Technology, 50(2), 735-749. https://doi.org/10.1111/bjet.12692

[35] King, A., Boysen-Osborn, M., Cooney, R., Mitzman, J., Misra, A., Williams, J., Dulani, T., \& Gottlieb, M. (2017). Curated Collection for Educators: Five Key Papers about the Flipped Classroom Methodology. Cureus, 9(10), e1801-e1801. PubMed. https://doi.org/10.7759/cureus.1801

[36] Kishore, A., Joseph, C. V., Bijili, L., Anwar, Md. A., \& Urvi. (2019). Co Ed: A Classroom Setup for Enhancing Cooperative Learning and Digital Literacy. Extended Abstracts of the 2019 CHI Conference on Human Factors in Computing Systems, 1-6. https://doi.org/10.1145/3290607.3309691

[37] Laabidi, Y., \& Laabidi, H. (2016). Barriers affecting successful integration of ICT in Moroccan universities. Journal of English Language Teaching and Linguistics, 1(3). https://doi.org/10.21462/jeltl.v1i3.29

[38] Levy, M. (1997). Computer-assisted language learning context and conceptualization (1st ed.). Oxford university press.

[39] López, J. (2017). The influence of ICT in the development of writing skills through an online platform. Matices En Lenguas Extranjeras, 11, 1944. https://doi.org/10.15446/male.n11.71852 
[40] Mathipa, E., \& Mukhari, S. (2014). Teacher factors influencing the use of ICT in teaching and learning in south African urban schools. Mediterranean Journal of Social Sciences, 5(23). https://doi.org/10.5901/mjss.2014.v5n23p1213

[41] McKnight, K., O'Malley, K., Ruzic, R., Horsley, M., Franey, J., \& Bassett, K. (2016). Teaching in a digital age: How educators use technology to improve student learning. Journal of Research on Technology in Education, 48(3), 194-211. https://doi.org/10.1080/15391523.2016.1175856

[42] Mena, J., Singh, B., \& Clarke, A. (2019). International Perspectives about ICT Implementation in the Classroom: Lessons for Teacher Education. Proceedings of the Seventh International Conference on Technological Ecosystems for Enhancing Multiculturality, 565-570. https://doi.org/10.1145/3362789.3362945

[43] Nikolopoulou, K., \& Gialamas, V. (2015). Barriers to ICT use in high schools: Greek teachers' perceptions. Computers in Education Journal, 3(1), 59-75. https://doi.org/10.1007/s40692-015-0052-z

[44] Papadima-Sophocleous, S., Giannikas, C., \& Kakoulli-Constantinou, E. (2014). ICT in EFL: the global effect of new technologies in the language classroom. Call Design: Principles and Practices, 296-300. https://doi.org/10.14705/rpnet.2014.000234

[45] Pérez, M. L., \& Malagón, C. G. (2017). Creating Materials with ICT for CLIL Lessons: A Didactic Proposal. Education, Health and ICT for a Transcultural World, 237, 633-637. https://doi.org/10.1016/j.sbspro.2017.02.029

[46] Pew Research Center. (2015). Internet seen as positive influence on education but negative on morality in emerging and developing nations. Pew Research Center. https://www.pewresearch.org/global/2015/03/19/1-communications-technology-in-emerging-and-developingnations/

[47] Player-Koro, C. (2012). Factors influencing teachers' use of ICT in education. Education Inquiry, 3(1), 93-108. https://doi.org/10.3402/edui.v3i1.22015

[48] Pourhosein, A. (2017). A Review of the Literature on the Integration of Technology into the Learning and Teaching of English Language Skills. International Journal of English Linguistics, 7(5). https://doi.org/10.5539/ijel.v7n5p95

[49] Prasad, C., Lalitha, P., \& Srikar, P. (2015). Barriers to the use of information and communication technology (ICT) in secondary schools: Teacher's perspective. Journal of Management Research, 7(2), 191-208. https://doi.org/10.5296/jmr.v7i2.6935

[50] Prensky, M. (2001). Digital Natives, Digital Immigrants Part 1. On the Horizon, 9(5), 1-6. https://doi.org/10.1108/10748120110424816

[51] Riddell, J., Jhun, P., Fung, C.-C., Comes, J., Sawtelle, S., Tabatabai, R., Joseph, D., Shoenberger, J., Chen, E., Fee, C., \& Swadron, S. P. (2017). Does the Flipped Classroom Improve Learning in Graduate Medical Education? Journal of Graduate Medical Education, 9(4), $491-496$. https://doi.org/10.4300/JGME-D-16-00817.1

[52] Rotellar, C., \& Cain, J. (2016). Research, Perspectives, and Recommendations on Implementing the Flipped Classroom. American Journal of Pharmaceutical Education, 80(2), 34. https://doi.org/10.5688/ajpe80234

[53] Sabri, T., Bushra, Q., \& Sunil, P. (2020). Computer-assisted language instruction in South Yemeni context: A study of teachers' attitudes, ICT uses and challenges. International Journal of Language Edition, 4(1), 59-73. https://doi.org/10.26858/ijole.v4i2.10106

[54] Sahlin, J. S., Tsertsidis, A., \& Islam, M. S. (2017). Usages and impacts of the integration of information and communication technologies (ICTs) in elementary classrooms: Case study of Swedish municipality schools. Interactive Learning Environments, 25(5), 561-579. https://doi.org/10.1080/10494820.2016.1170045

[55] Salem, N., \& Mohammadzadeh, B. (2018). A study on the integration of ICT by EFL teachers in Libya. EURASIA Journal of Mathematics, Science and Technology Education, 14(7), 2787-2801. https://doi.org/10.29333/ejmste/90594

[56] Sari, A., Rochsantiningsih, D., Suryani, N., \& Suharno, M. (2017). Teachers' Perceptions Towards Digital-Based Teaching Material. International Conference on Teacher Training and Education 2017 (ICTTE 2017), 881-888. https://doi.org/10.2991/ictte-17.2017.100

[57] Solano, L., Cabrera, P., Ulehlova, E., \& Espinoza, V. (2017). Exploring the use of educational technology in EFL teaching: A case study of primary education in the south region of Ecuador. Teaching English with Technology, 17, 77-86.

[58] Stein, J., Graham, C. R., \& Francis, T. \&. (2020). Essentials for Blended Learning, 2nd Edition: A Standards-Based Guide. Routledge. https://books.google.com.ec/books?id=1-QzzAEACAAJ

[59] Tafazoli, D., \& Golshan, N. (2014). Review of computer-assisted language learning: History, merits \& barriers. International Journal of Language and Linguistics, 2, 32-38. https://doi.org/10.11648/j.ijll.s.2014020501.15

[60] Taylor, D., \& Packham, G. (2016). Social Inclusion through ICT: Identifying and Overcoming Barriers to ICT Use. Strategic Change, 25(1), 4560. https://doi.org/10.1002/jsc.2046

[61] Toledo, H., \& Campuzano, J. (2017). Exploring the role of technology through collaborative learning in Ecuadorian language education. INNOVA Research Journal, 2(10), 1-11.

[62] Wang, X. (2017). Analysis of advantages and disadvantages of multimedia teaching. 7th International Conference on Management, Education, Information and Control (MEICl 2017), 693-695. https://doi.org/10.2991/meici-17.2017.137

[63] Warschauer, M., \& Healey, D. (1998). Computers and language learning: An overview. Language Teaching, 31(2), 57-71. Cambridge Core. https://doi.org/10.1017/S0261444800012970

[64] Wiseman, A. W., Al-bakr, F., Davidson, P. M., \& Bruce, E. (2018). Using technology to break gender barriers: Gender differences in teachers' information and communication technology use in Saudi Arabian classrooms. Compare: A Journal of Comparative and International Education, 48(2), 224-243. https://doi.org/10.1080/03057925.2017.1301200

[65] Xu, A., \& Chen, G. (2016). A study on the effects of teachers' information literacy on information technology integrated instruction and teaching effectiveness. Eurasia Journal of Mathematics, Science \& Technology Education, 12(2), 335-346. https://doi.org/10.12973/eurasia.2016.1222a

[66] Zainuddin, Z., \& Attaran, M. (2016). Malaysian students' perceptions of flipped classroom: A case study. Innovations in Education and Teaching International, 53(6), 660-670. https://doi.org/10.1080/14703297.2015.1102079 